\title{
Meteorological Analysis for Fenton Hill, 1979
}

\author{
Sumner Barr \\ S. Kerry Wilson
}

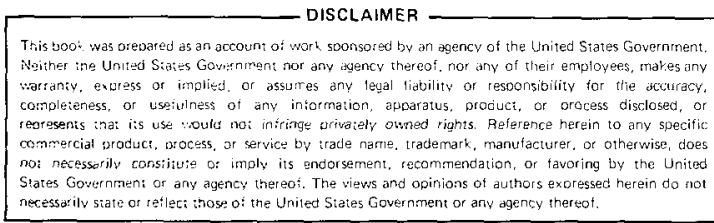




\section{DISCLAIMER}

This report was prepared as an account of work sponsored by an agency of the United States Government. Neither the United States Government nor any agency Thereof, nor any of their employees, makes any warranty, express or implied, or assumes any legal liability or responsibility for the accuracy, completeness, or usefulness of any information, apparatus, product, or process disclosed, or represents that its use would not infringe privately owned rights. Reference herein to any specific commercial product, process, or service by trade name, trademark, manufacturer, or otherwise does not necessarily constitute or imply its endorsement, recommendation, or favoring by the United States Government or any agency thereof. The views and opinions of authors expressed herein do not necessarily state or reflect those of the United States Government or any agency thereof. 


\section{DISCLAIMER}

Portions of this document may be illegible in electronic image products. Images are produced from the best available original document. 
METEOROLOGICAL ANALYSIS FOR FENTON HILL, 1979

by

Sumner Barr and S. Kerry Wilson

\section{ABSTRACT}

Three years of meteorological data have been collected at the Fenton Hill site to establish a local climatic baseline, transport and diffusion climatology, and an initial site for an eventual Valles Caldera meteorological network. Towerbased wind and temperature data at $15 \mathrm{~m}$ above ground were supplemented during 1979 with precipitation, humidity and pressure measurements,. and a limited program of upper winds. Preliminary analysis of the data has been made to identify major topographic and meteorological driving forces affecting the local climatic variations on diurnal and seasonal time scales. The site is quite high and exposed enough that external influences such as gradient wind flow and thunderstorms tend to dominate over purely local driving forces in determining climate. Locally generated wind circulations are identifiable at night but tend to be weak and sporadic. The presence of topographic obstacles on the 10- to $100-\mathrm{km}$ scale is observed in the winds. 


\section{INTRODUCTION}

Three years of meteorological data have been collected at the Fenton Hill Hot Dry Rock geothermal site in the Jemez mountains in support of environmental studies. One planned purpose of the data is to establish a local climatic baseline against which possible induced climate changes may be evaluated. Also, it is important to have estimates of the wind field to maintain the capability to assess the transport of airborne pollutants that may emanate from the drilling and heat-exchange operations. In view of proposed expansion of a geothermal industry in the Valles Caldera area, good estimates of the meteorological structure will be invaluable in identifying the correct sources of trace gases such as $\mathrm{H}_{2} \mathrm{~S}$. An additional requirement for meteorological data is in engineering design and operational safety questions (e.g. temperature, pressure, wind chill, structural wind loading). As industrial activity increases in the Valles Caldera, the Fenton Hill meteorological site will become an important baseline station in a network of observation sites. With these considerations in mind we have conducted an analysis on the first three years of record and designed an expanded measurement systen that will allow us to address a broader range of questions. Sections II and III of this report describe the analyses of the existing data set and Section IV describes the updated meteorological system.

II. SURFACE METEOROLOGICAL SURVEY

Winds and temperature have been recorded since 1976 by means of a mechanical weather station mounted on a 15-m tower. Pressure and humidity have been recorded during 1979 in an instrument shelter at $1.5 \mathrm{~m}$ above ground. Figure 1 shows the locations of the tower and shelter on the Fenton Hill site. Supplemental upper air data were collected using pilot balloons on an approximately weekly case study basis.

Figure 2 shows the Fenton Hill location in relation to the entire Jemez mountain complex. The site is at 2651-m elevation on a relatively flat knoll that separates two major canyons. The fetch from the southeast through west to northwest is quite unobstructed although winds with significant northerly or easterly components must pass over or around 
topography above $3300 \mathrm{~m}$. Several questions of topographic influence enter into the analysis of wind observations. If we can determine some topographic driving influences such as drainage or obstacle flow phenomena, then we have a basis for estimating the region of representativeness of a single wind station and a basis for estimating air trajectories and potential pollution receptor locations.

Figures $3 a-3 d$ show wind roses for each season compiled from the three year record. Winter has a west to northwest predominance that gradually gives way through spring to a southerly maximum occurrence in summer. Autumn and Spring wind roses are quite similar. Figure 4 shows a breakdown of the winter wind rose by diurnal periods. The most distinctive difference from midday to nocturnal conditions is the growth of a northerly maximum in the moderate speed range. The summer nighttime winds reflect a dominant component from the southeast that gives way to southerly and westerly dominance during the day accompanied by an increase in wind speed as shown in Fig. 5. A secondary maximum occurrence of northerly flow at night is similar to the winter night case.

We can attempt to identify the major driving forces for the winds and to distinguish diurnal and seasonal differences in driving force that relate to the variations in winds. The daytime winds generally reflect the large-scale pressure gradient flow which exhibits westerly dominance throughout the year in northern New Mexico. The winter northwesterly and summer southerly components are consistent with the seasonal pressure patterns. The situation at night becomes somewhat more complicated. On some nights local temperature differences on sloping surfaces produce local circulations that are generally shallow and frequently are decoupled from wind fields that exist above by virtue of very stable vertical temperature lapse rates that strongly damp turbulent momentum transfer. On other nights the mechanical turbulence generated by the interaction of the large scale winds with the ground is sufficient to overwhelm the locally driven winds. An intermediate phenomenon is the addition of two approximately equal wind vectors to produce an airflow between the purely local wind and a synoptically forced flow. An important part of the study of topographically complex sites is to identify the major forcing functions and the conditions under which they interact. Variables affecting the balance 
include large-scale wind speed and direction, cooling parameters including cloud cover, atmospheric moisture, terrain surface orientation, moisture, and snow cover. Two features of the wind roses reflect local wind patterns on perhaps two different scales. First, the northerly wind in both winter and summer lines up with a weakly defined topographic channel between the San Pedro mountains and Redondo Peak and also with San Antonio creek canyon which borders the site. The other characteristic feature is an easterly component that exists at night but is seldom observed during the day. The easterly wind appears to be vectorially added to the existing gradient flow producing resultant winds that include northeast and southeast directions. The source of the easterly component could be a slope wind induced by Redondo Peak or the initial stages of drainage flow into one of two canyons that border the site on the northeast and south sides, respectively.

Another presentation that is useful for describing diurnal wind patt terns is the seasonal composite hodograph, shown in Fig. 6a-6d. Vector mean winds for each clock-hour in the sample are calculated and plotted as the tail of the vector with its head at the origin. The resulting hodograph reflects a systematic variation of the wind throughout the diurnal period. The seasonal grouping tends to combine winds that result from an assortment of external transient forces such as synoptic gradient flows. This grouping therefore will yield the diurnal variation about a prevailing wind. Since large-scale winds are generally lighter in summer the hodographs for that season are more likely to reflect locally driven wind patterns.

The winter hodograph indicates winds from the northwest quadrant through the nocturnal period with westerly components near midday. This is fully consistent with the wind rose format. The diurnal hodograph for spring is very similar to winter in its general shape except that daytime winds are slightly stronger with a distinct southwesterly component. The progression of the wind vectors through the day is in the sense of turning clockwise or veering with time. 
The summer pattern is quite different. Southwest winds during the day change somewhat abruptly to easterly at about sunset. An equally rapid transition to the daytime regime occurs near sunrise. The fall season also shows a binary preference for northwest flow at night and slightly stronger west to southwest wind in the day with a fairly rapid transition between the two regimes.

In an effort to relate surface based wind observations to an indicator of the large-scale synoptic flow, a pair of one month samples, representative of winter and summer seasons, were selected and scatter diagrams, Figs. 7a-7d were made. The $700 \mathrm{mill}$ ibar (approximately $3 \mathrm{~km}$ above sea level) wind direction from the Albuquerque radiosondes at 0500 MST and 1700 MST were chosen to represent the free air wind direction near the altitude of Fenton Hill and concurrent surface winds at Fenton Hill are plotted against this indicator. The winter afternoon shows a good correlation between large-scale flow and the surface winds. At night, the correiation remains good except for two departures. There is a tendency for the Fenton Hill winds to be shifted about $30^{\circ}$ to the north from the free air wind direction. This could be the result of channeling between Redondo Peak and the San Pedro mountains. The other exception is a small cluster of points showing northeasterly surface flow with west to northwest wind in the free atmosphere. The easterly component may reflect a de-coupled surface wind of local origin. The summer nocturnal winds are essentially uncorrelated with the free air wind directions (Fig. 7c). The correlation between daytime wind directions is not much higher. Apparently, some nonpersistent local effect (e.g., thermal convection) has an influence on the local surface winds.

Tables I-III present selected statistics on temperature and precipitation for the three year record of data.

\section{WINDS ALOFT SURVEY}

Surface meteorological data tends to be influenced by local topographic and vegetative features and one good way to assess the usefulness of a measurement point for estimating trajectories that cover an area about the point is to obtain vertical soundings above that location. 
TABLE I

FENTON HILL METEOROLOGICAL DATA FOR 1976

\begin{tabular}{|c|c|c|c|c|c|c|c|c|c|c|}
\hline & \multicolumn{7}{|c|}{ Temperatures $\left({ }^{\circ} \mathrm{C}\right)$} & \multicolumn{3}{|c|}{ Precipitation(min) } \\
\hline & \multicolumn{3}{|c|}{ Average } & \multicolumn{4}{|c|}{ Extremes } & \multirow[b]{2}{*}{ Total } & \multirow[b]{2}{*}{$\begin{array}{c}\text { Greatest } \\
\text { Day }\end{array}$} & \multirow[b]{2}{*}{ Date } \\
\hline & $\begin{array}{l}\text { Daily } \\
\text { Max. }\end{array}$ & $\begin{array}{l}\text { Daily } \\
\text { Min. }\end{array}$ & Monthly & Highest & Date & Lowest & Date & & & \\
\hline January & 0 & -10 & -6 & 8 & 28 & -22 & 2 & 4.8 & 3.3 & 24 \\
\hline February & 1 & -6 & -3 & 8 & 1 & -16 & 21 & 41.4 & 11.4 & 13 \\
\hline March & 1 & -7 & -3 & 9 & 25 & -17 & 5 & 17.5 & 4.3 & 28 \\
\hline April & 6 & -2 & 2 & 12 & 10 & -13 & 17 & 21.1 & 10.4 & 15 \\
\hline May & 12 & 2 & 7 & 18 & 15 & -6 & 8 & 45.0 & 21.8 & 6 \\
\hline June & 19 & 8 & 14 & 26 & 28 & 2 & 15 & 6.7 & 3.5 & 6 \\
\hline July & 19 & 10 & 14 & 25 & 10 & 4 & 24 & 74.9 & 18.8 & 21 \\
\hline August & 18 & 9 & 13 & 23 & 12 & 4 & 2 & 69.1 & 15.8 & 18 \\
\hline September & 14 & 6 & 10 & 22 & 4 & -1 & 28 & 45.7 & 10.7 & 20 \\
\hline October & 7 & 0 & 3 & 18 & 10 & -7 & 19 & 4.8 & 3.3 & 23 \\
\hline November & 2 & -2 & -1 & 12 & 6 & -23 & 28 & 17.5 & 17.5 & 27 \\
\hline December & 1 & -7 & -4 & 8 & 3 & -13 & 6 & 8.6 & 5.3 & 31 \\
\hline Year & 8.3 & 0.1 & 3.8 & 26 & $6 / 28$ & -23 & $11 / 28$ & 356.5 & 18.8 & $7 / 21$ \\
\hline
\end{tabular}




\section{TABLE II}

FENTON HILL METEOROLOGICAL DATA FOR 1977

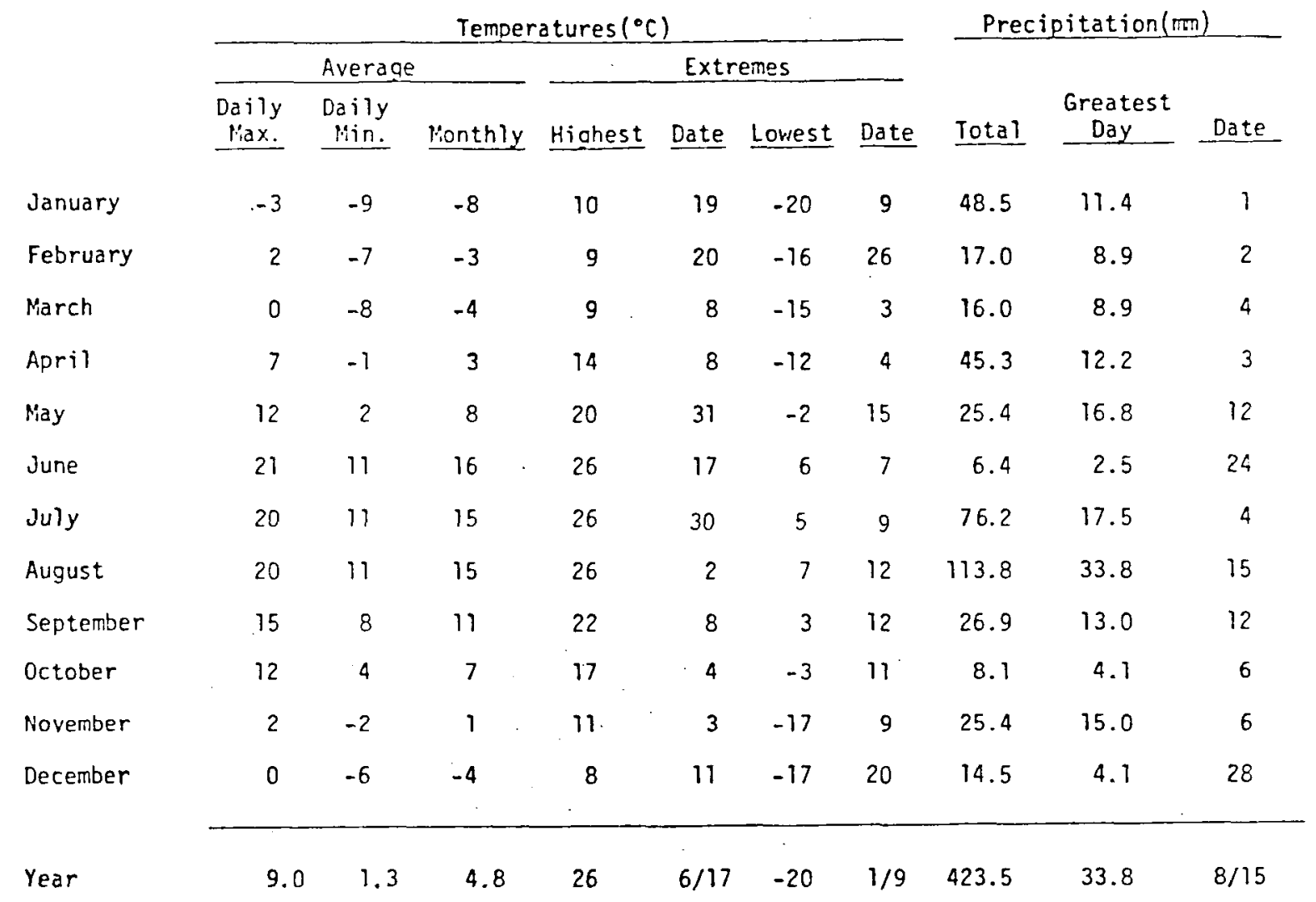


TABLE II I

FENTON HILL METEOROLOGICAL DATA FOR 1978

\begin{tabular}{|c|c|c|c|c|c|c|c|c|}
\hline \multicolumn{6}{|c|}{ Temperatures $\left({ }^{\circ} \mathrm{C}\right)$} & \multicolumn{3}{|c|}{ Precipitation(nm) } \\
\hline & Average & & Extr & emes & & & & \\
\hline $\begin{array}{l}\text { Daily } \\
\text { Max. }\end{array}$ & $\begin{array}{l}\text { Daily } \\
\text { Min. }\end{array}$ & Monthly & Highest Date & Lowest & Date & Total & $\begin{array}{c}\text { Greatest } \\
\text { Day } \\
\end{array}$ & Date \\
\hline
\end{tabular}

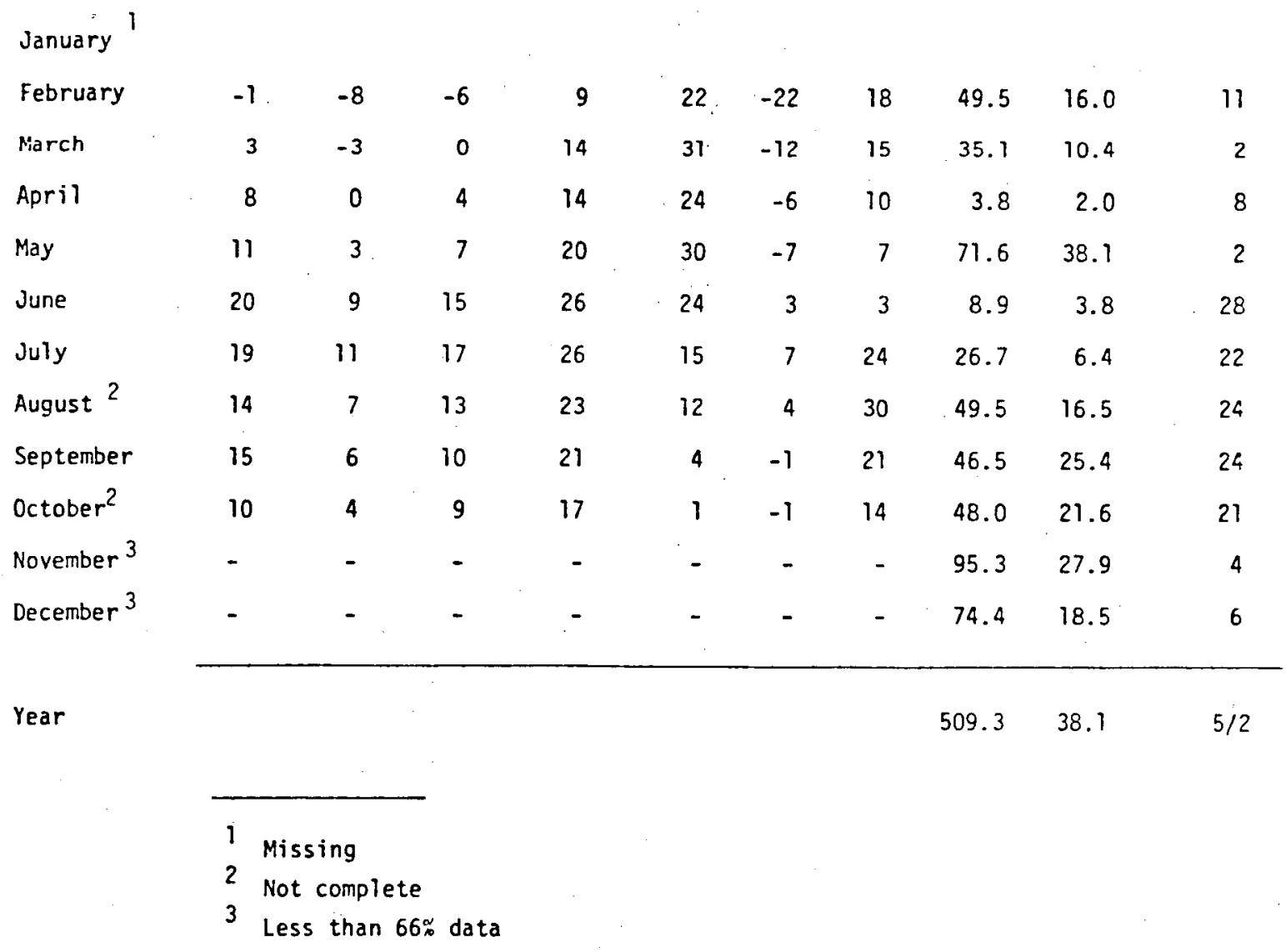


Local influences that dominate winds near the ground tend to diminish with altitude leaving a greater spatial coherence of wind measurements at several hundred meters above ground. A program of soundings for winds aloft was established to address several questions including:

- how well do Albuquerque upper winds represent the free air winds (above boundary domination) at Fenton Hill?

- how representative are surface based tower measurements for plume transport estimates from Fenton Hill site?

- are there consistencies in the structure of the wind profiles that can lead to an understanding of the basic phenomena governing the local wind climatology?

The technique required to measure wind aloft is a labor intensive manual method so the data set is smaller than the surface observations. A series of soundings were made on an approximately weekly basis when weather permitted between February and September, 1979. A summary of the soundings is given in Table IV. Surface wind directions are well correlated with the winds aloft. The root mean square departure between the two sets of observations is only 26.6 degrees. Winds at three altitudes were chosen for comparison with Albuquerque winds at the equivalent height. The levels, $3.0,3.5$ and $4.0 \mathrm{~km}$ above sea level (MSL) represent elevations near the major ridge tops in the area, near the highest peak, and well above topographic obstacles, respectively. The standard deviation of the departures between Fenton $\mathrm{Hill}$ and Albuquerque wind directions decreases with altitude, suggesting some terrain effect at $3.0 \mathrm{~km}$ that is significantly reduced by $4.0 \mathrm{~km} \mathrm{MSL}$. The mean and standard deviation of departures are given in Table $V$. 
TABLE IV

SUMMARY OF WINDS ALOFT SURVEY

key: wind speed/wind direction (degrees)

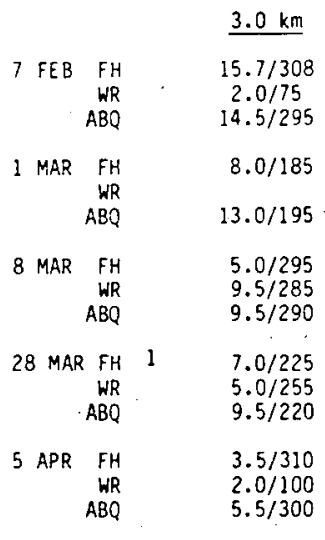

$3.5 \mathrm{~km}$

$4.0 . \mathrm{km}$

$\mathrm{FH}$

Surface

Wind

$6.9 / 301$

$700 \mathrm{MB}$

$24.0 / 305$
$5.5 / 280$

$24.0 / 305$

Wind

$19.0 / 310$

$19.5 / 305$

$15.4 / 325$

$13.0 / 205$

$16.0 / 225$

$16.0 / 205$

$17.5 / 215$

$18.0 / 290$

$9.5 / 285$

$13.0 / 295$
$15.0 / 295$

$9.0 / 285$

$9.77 / 290$

$11.5 / 210$

$17.0 / 205$

$9.5 / 220$

$2.0 / 010$

$4.0 / 275$

$6.0 / 310$

$8.5 / 275$

$5.4 / 290$

11 APR $\underset{H R}{F} \quad \begin{array}{r}17.0 / 300 \\ \text { HR }\end{array}$

$\begin{array}{rr}\text { HR } & 7.0 / 290 \\ \text { ABQ } & 14.0 / 290\end{array}$

$10.0 / 280$

$19.0 / 280$

$14.0 / 285$

$13.5 / 290$

18 APR FH $\quad 12.0 / 180$

$\begin{aligned} \text { WR } & 11.0 / 205 \\ \text { ABO } & 10.5 / 195\end{aligned}$

$7.0 / 240$

$16.0 / 200$

$11.0 / 200$

$12.0 / 220$

$8.0 / 210$

$13.0 / 230$

25 APR FH $\quad 9.0 / 295$

$\begin{array}{rr}\text { WR } & 10.0 / 275 \\ \text { ABQ } & 15.5 / 310\end{array}$

$10.5 / 295$

$6.0 / 280$

9.0/295

$9.0 / 295$
$6.5 / 295$

$15.5 / 295$

$16 \mathrm{MAY} \mathrm{FH} \quad 6.5 / 245$

WR $\quad 5.0 / 230$

$5.5 / 210$

$5.5 / 220$

$4.0 / 225$

$9.0 / 195$

$10.5 / 240$

4. $0 / 350$

$3.5 / 50$
$4.0 / 330$

$5.5 / 300$

$6.5 / 15$
$7.0 / 315$

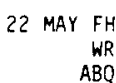

$3.0 / 55$
$2.0 / 80$
$3.0 / 345$

$3.0 / 345$

30 MAY FH

$6.0 / 245$

$13.5 / 215$

$8.0 / 215$

$11.0 / 225$

$11.5 / 240$

$10.0 / 245$

$7.5 / 250$

6 JUN FH $\quad 6.6 / 302$

$7.1 / 298$

$7.2 / 310$

$11.1 / 316$

$12.1 / 320$

$8.0 / 310$

13 JUN FH $3.1 / 162$

$3.1 / 162$
$8.2 / 203$
$8.7 / 189$

$4.4 / 220$

$8.3 / 221$
$6.5 / 177$

$3.9 / 260$

$8.6 / 243$

$6.0 / 205$

$6.3 / 284$

$8.4 / 294$

$1.2 / 270$

$1.7 / 207$

$4.4 / 184$

$2.68 / 301$

$3.2 / 175$

5 JUL FH $\quad 2.9 / 100$

$4.0 / 241$

4.0/195

$3.4 / 200$

$3.5 / 327$

$3.6 / 17$

$6.1 / 337$

$4.6 / 11$

$7.7 / 319$

$9.4 / 195$

$4.4 / 304$

$3.4 / 203$

$4.2 / 92$

$4.1 / 267$

4.6/249

$3.1 / 203$

$8.0 / 180$

$2.5 / 242$

$3.5 / 327$

$6.1 / 337$

$4.1 / 288$

$6.1 / 337$

$2.7 / 170$

$8.1 / 297$

$1.7 / 192$

3.0/158

$3.0 / 142$

4.1/291

9.0/291

$16.6 / 287$

$9.4 / 308$

$6.9 / 185$

2.3/277

$5.2 / 227$

$9.1 / 260$

$5.7 / 203$ 
TABLE V

MEAN AND STANDARD DEVIATION OF DEPARTURES BETWEEN SIMULTANEOUS PAIRS

OF WIND DIRECTION OBSERVATIONS

\begin{tabular}{|c|c|c|}
\hline Observation Pair & Mean, degrees & Standard Deviation, degrees \\
\hline $\begin{array}{c}\text { Fenton Hill } 3.0 \mathrm{~km} \\
A B Q 3.0 \mathrm{~km}\end{array}$ & 12.5 & 54.5 \\
\hline $\begin{array}{c}\text { Fenton } \mathrm{Hill} 3.5 \mathrm{~km} \\
\mathrm{ABQ} 3.5 \mathrm{~km}\end{array}$ & -0.5 & 40.8 \\
\hline $\begin{array}{c}\text { Fenton } \mathrm{Hil1} 4.0 \mathrm{~km} \\
A B Q 4.0 \mathrm{~km}\end{array}$ & 1.5 & 28.1 \\
\hline $\begin{array}{l}\text { Fenton } \mathrm{Hill} \text { surface } \\
\text { Fenton } \mathrm{Hill} 3.0 \mathrm{~km}\end{array}$ & -2.0 & 26.6 \\
\hline
\end{tabular}

IV. METEOROLOGICAL MEASUREMENT SYSTEM

An updated tower-based meteorological observation and recording system has been designed and recently installed at the Fenton $\mathrm{Hill}$ site. In addition to wind direction and speed and temperature at two levels $(4 \mathrm{~m}$ and 20 $\mathrm{m})$; precipitation, humidity, and pressure are recorded hourly on magnetic tape casettes. The new system will run concurrently with the existing tower for a comparison period of six months in order to document changes in the data that may arise from differences in location, instrumentation, recording, and reduction methods.

Analysis software is currently being prepared that will hopefully lead to a product that is useful for climate documentation, pollutant transport estimation and HDR operations support as well as establishing a baseline for a future Valles Caldera meteorological network. Preliminary analysis products will be distributed to interested parties and we will solicit reactions on their utility prior to setting up final analysis procedures. 


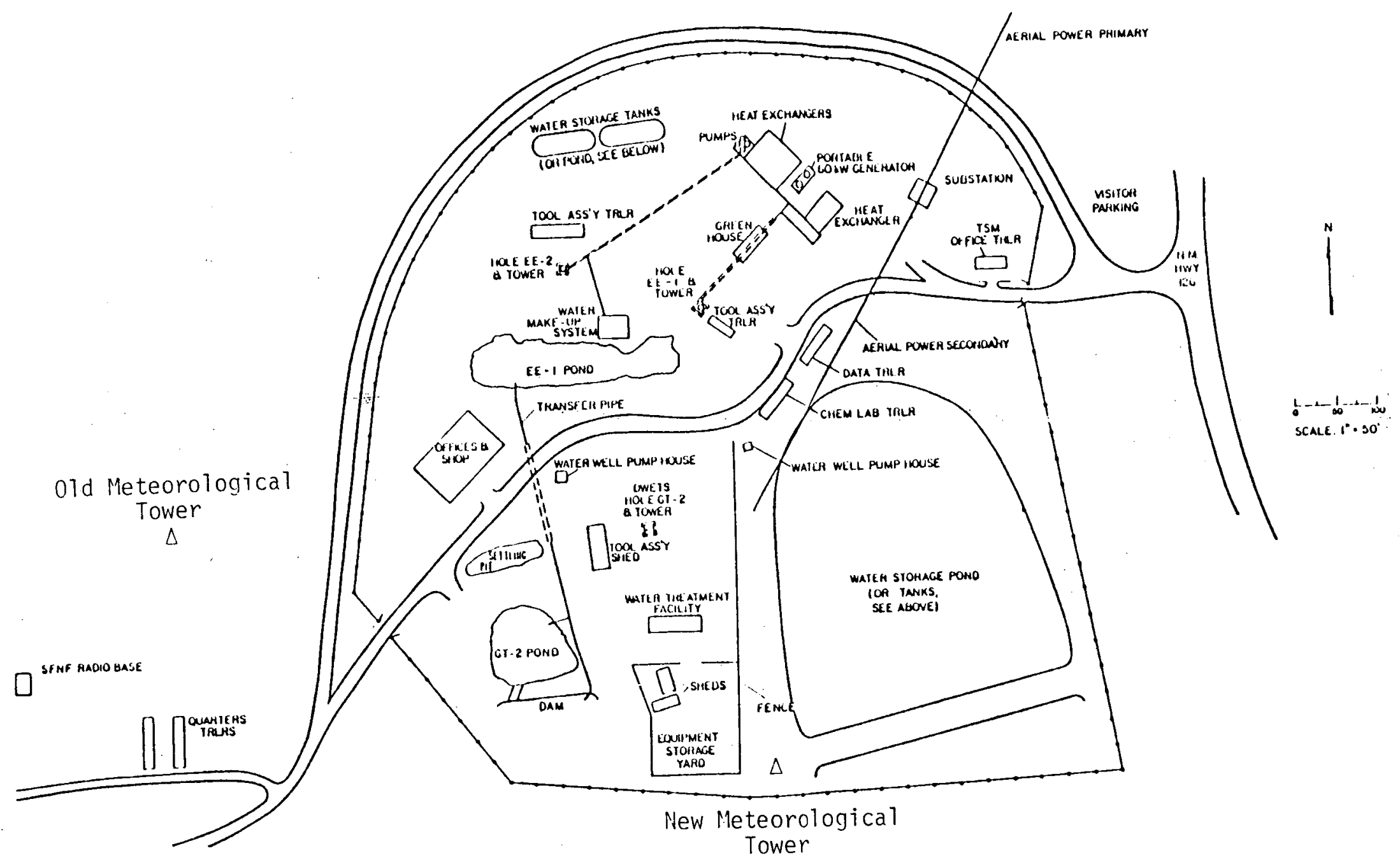

Fig. 1. Plan view of Fenton Hill site. 


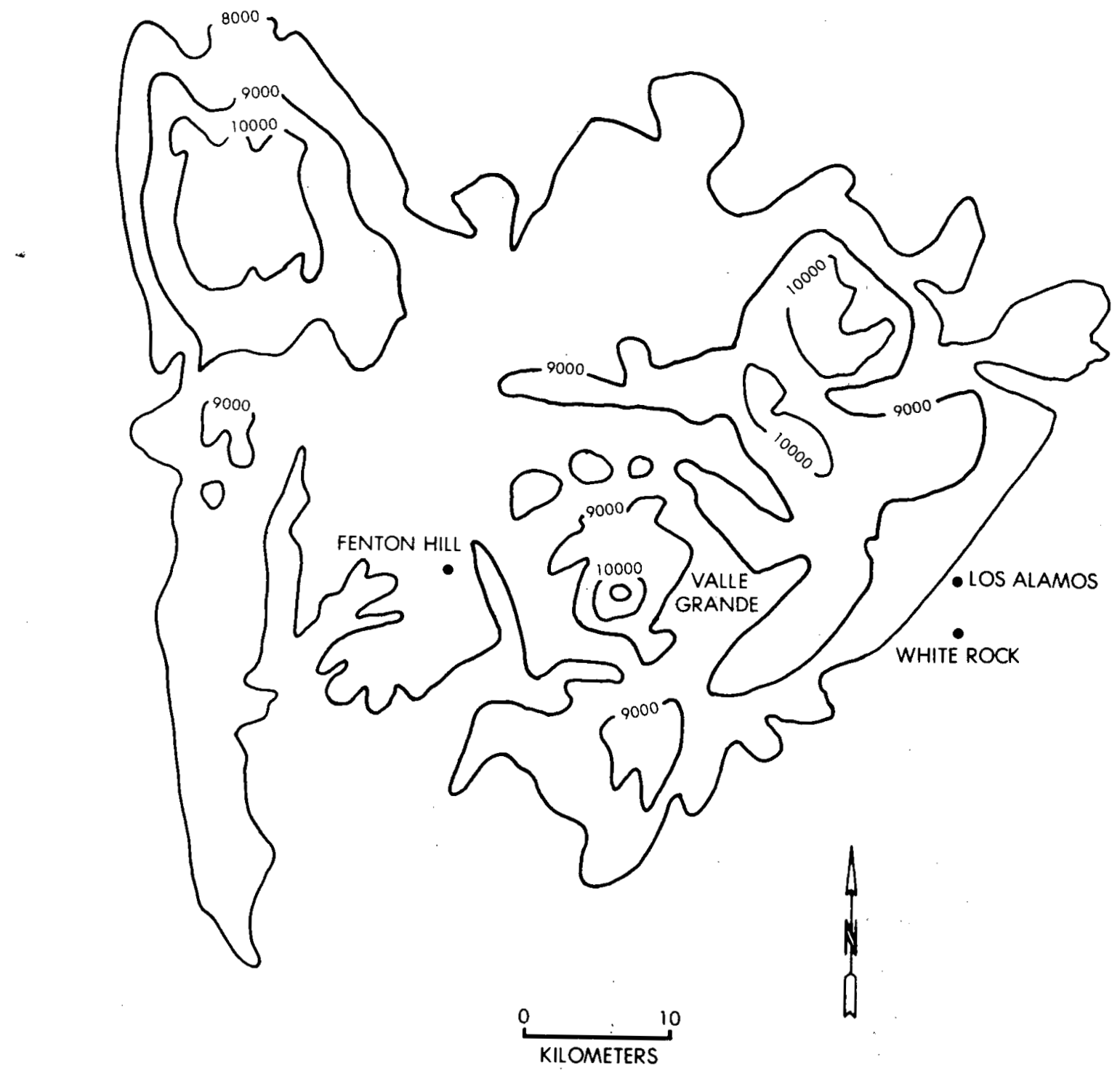

Fig. 2. Topographic diagram of the Valles Caldera area, including Fenton Hill. 


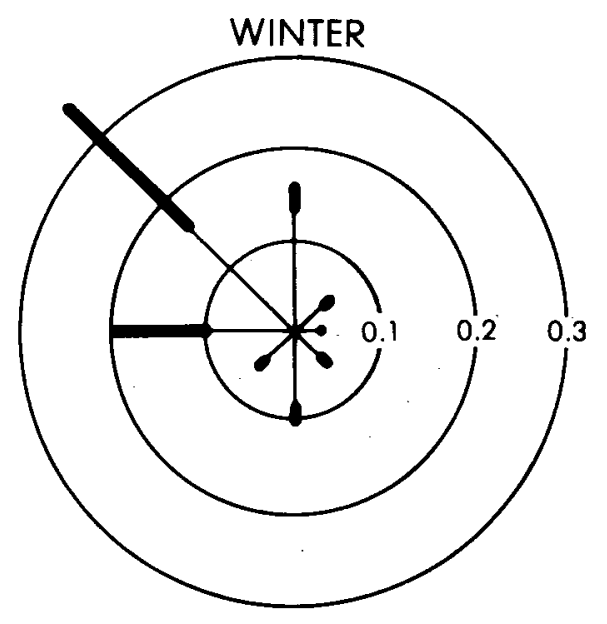

Fig. 3a.

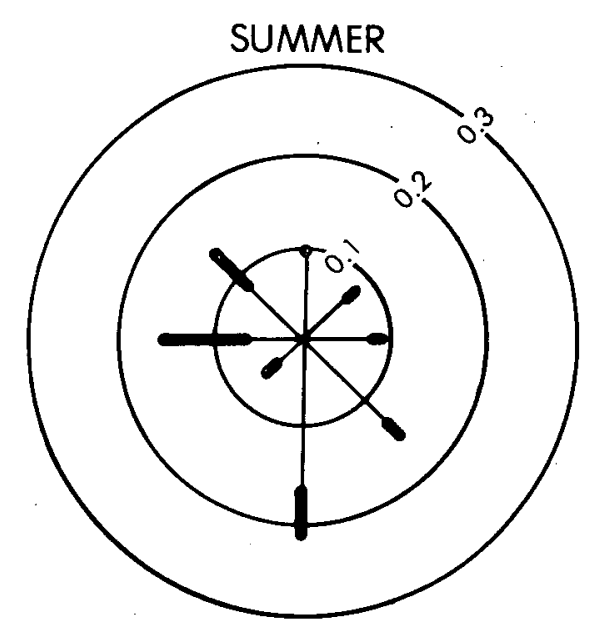

Fig. 3c.

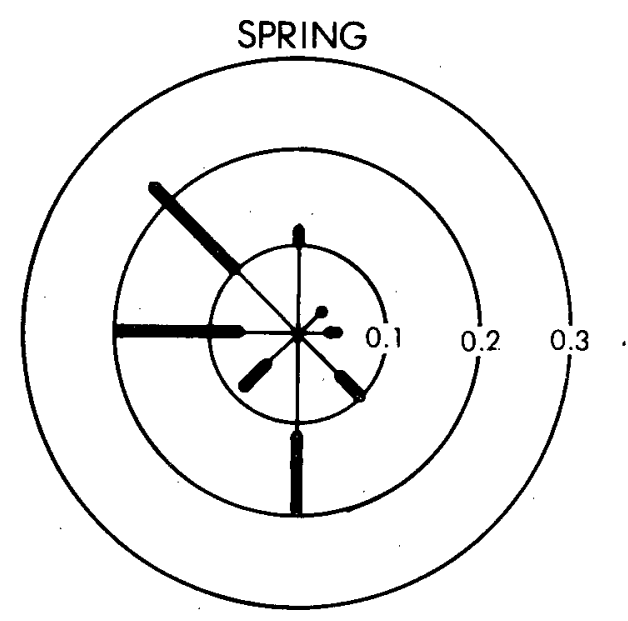

Fig. 3b.

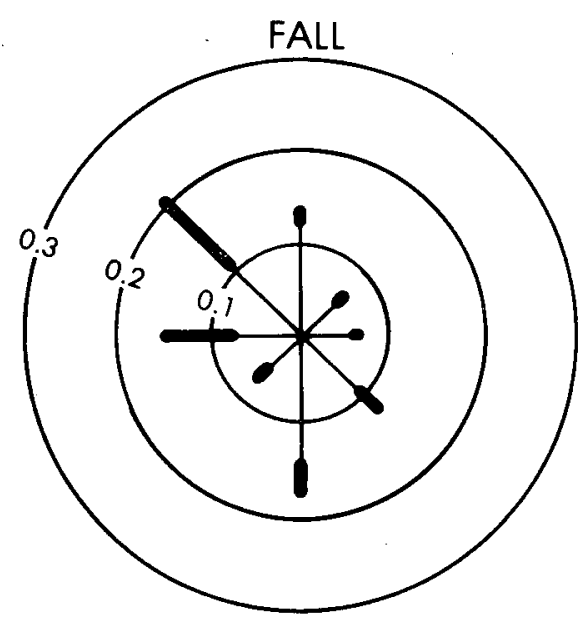

Fig. 3d.

Fig. 3. Seasonal wind roses, all hours combined. 


\section{WINTER}
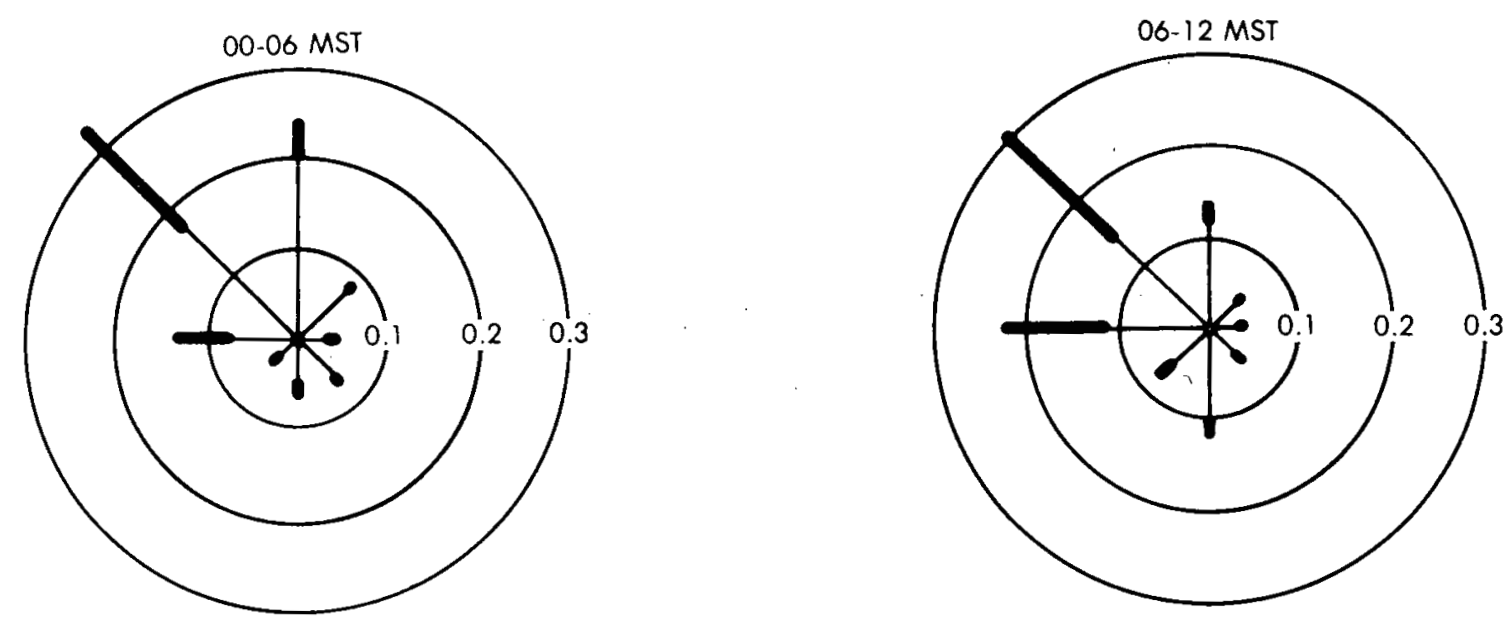

Fig. $4 a$.

Fig. 4b.
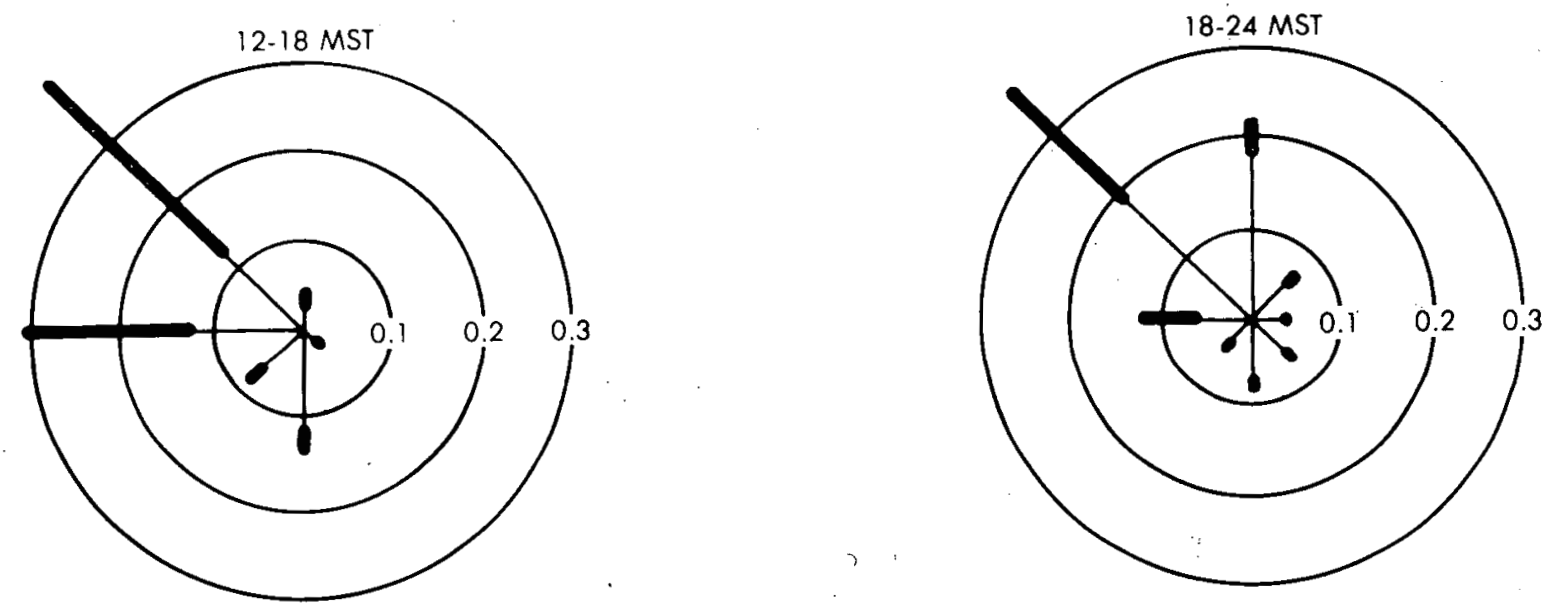

Fig. $4 c$.

Fig. $4 d$.

Fig. 4. Wind roses for four periods of the day, winter. 


\section{SUMMER}

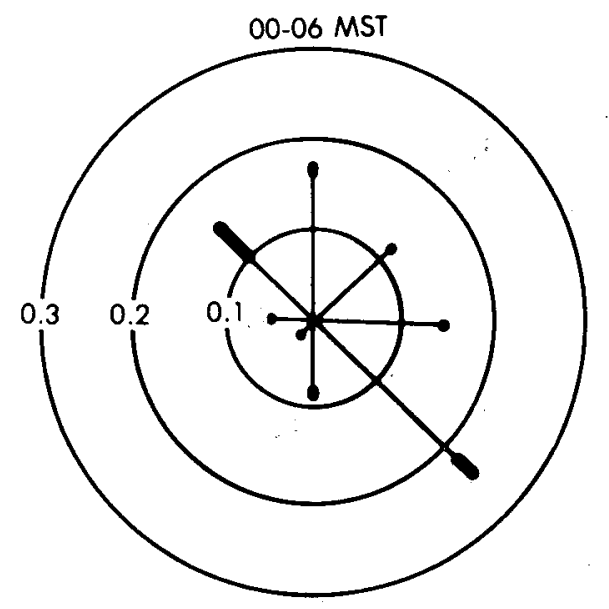

Fig. 5a.

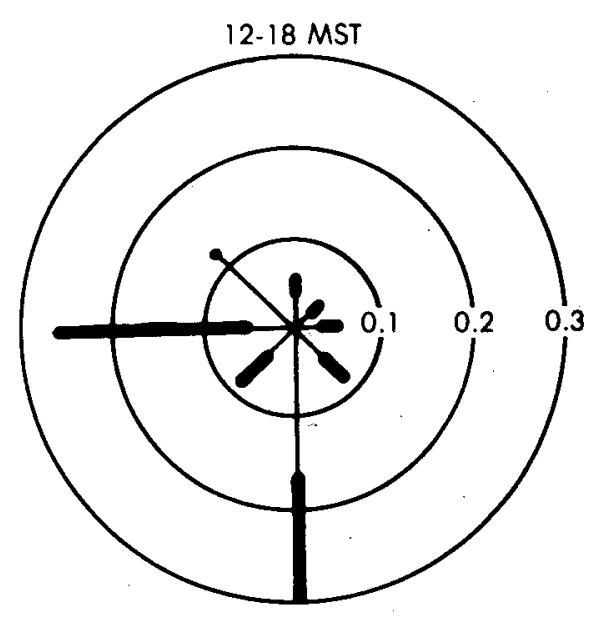

Fig. 5c.

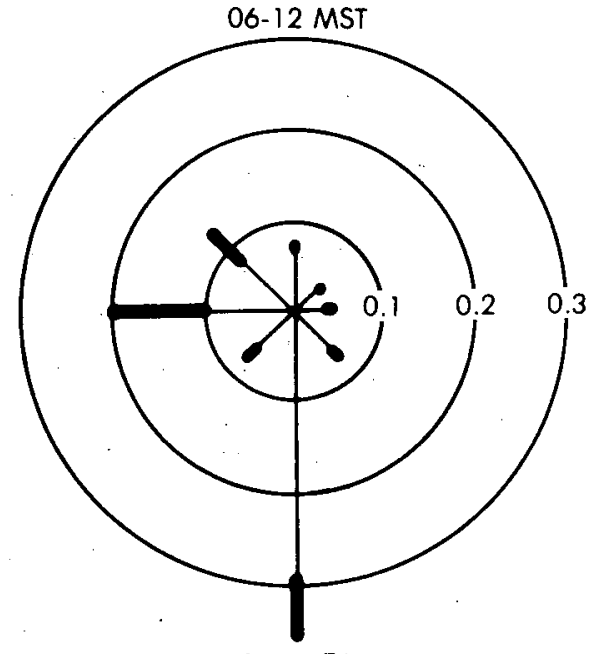

Fig. 5b.

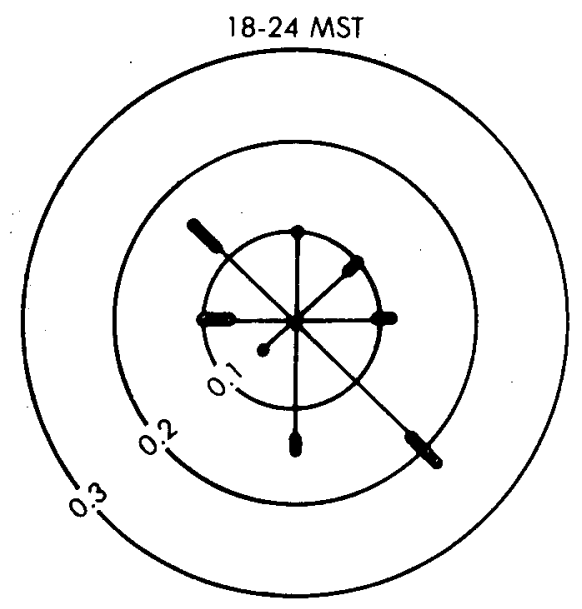

Fig. $5 d$.

Fig. 5. Wind roses for four periods of the day, summer. 

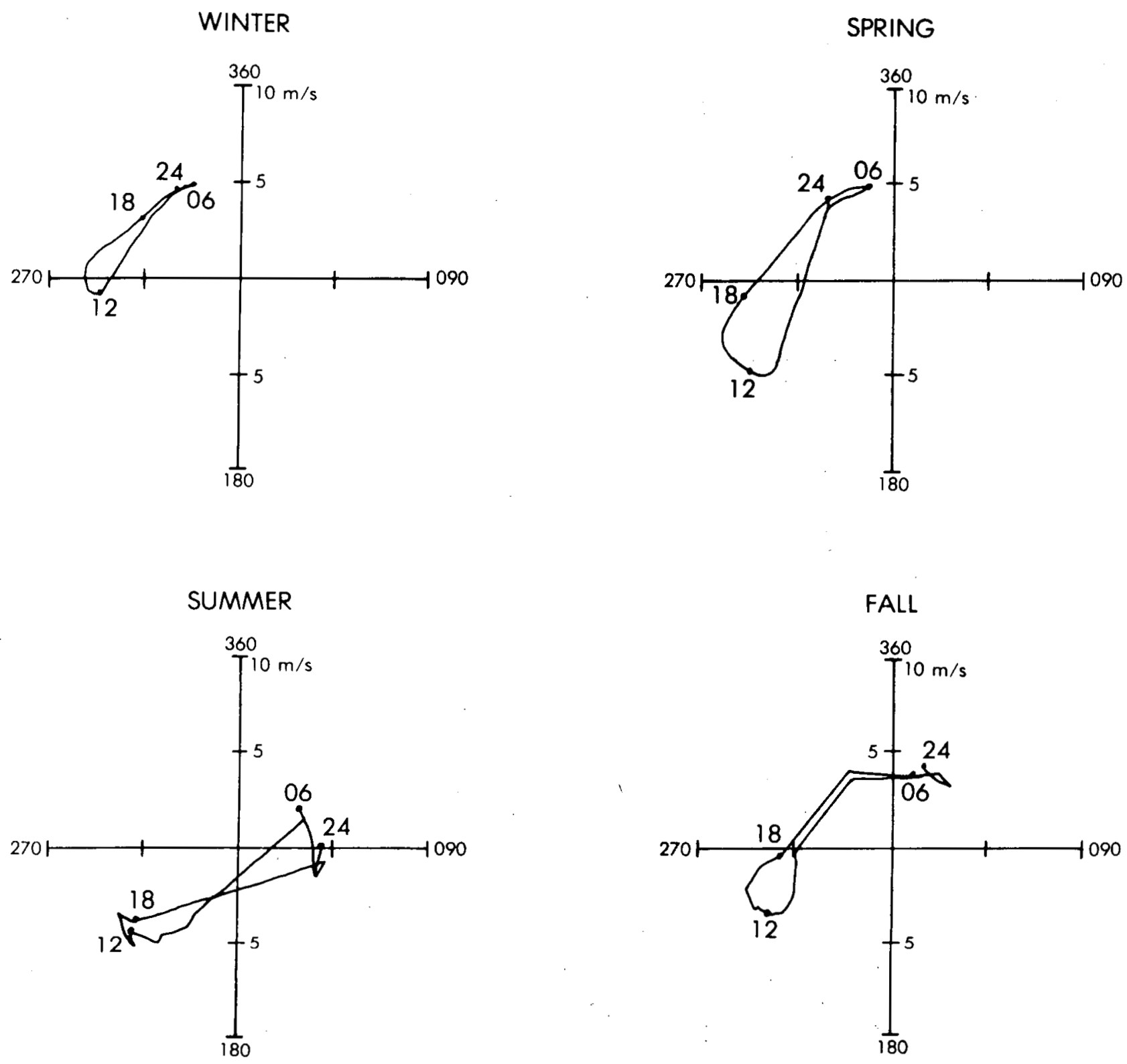

Fig. 6. Diurnal hodographs for each season of the year. Wind blows from the plotted curve to the origin. 
1

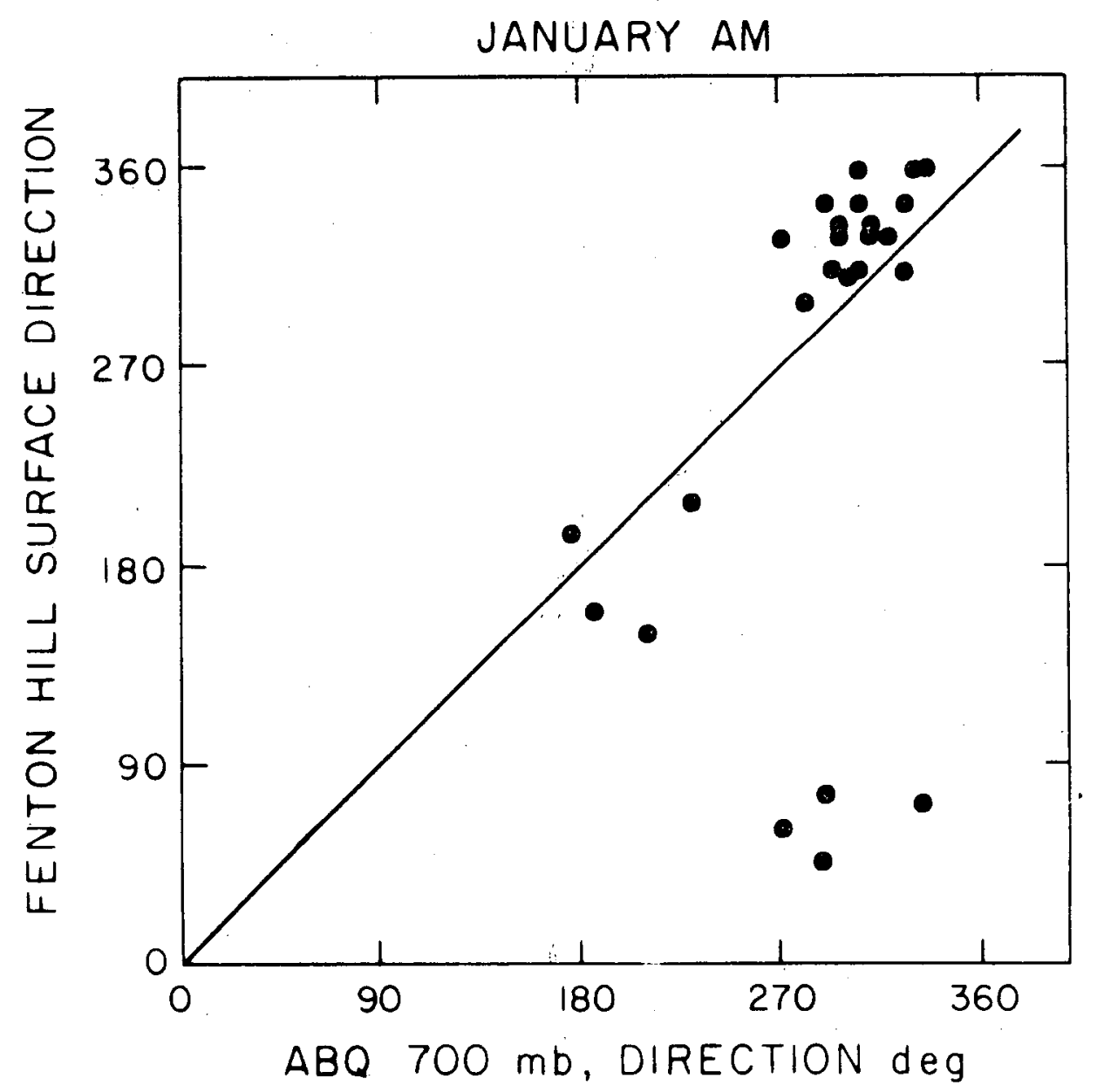

Fig. 7a. Scatter diagram relating surface $(2.7 \mathrm{~km} \mathrm{MSL})$ wind direction at Fenton $\mathrm{Hili}$ to the $700 \mathrm{mb}(3 \mathrm{~km} \mathrm{MSL})$ level winds from the Albuquerque upper air. sounding. Comparisons are for winter mornings. 


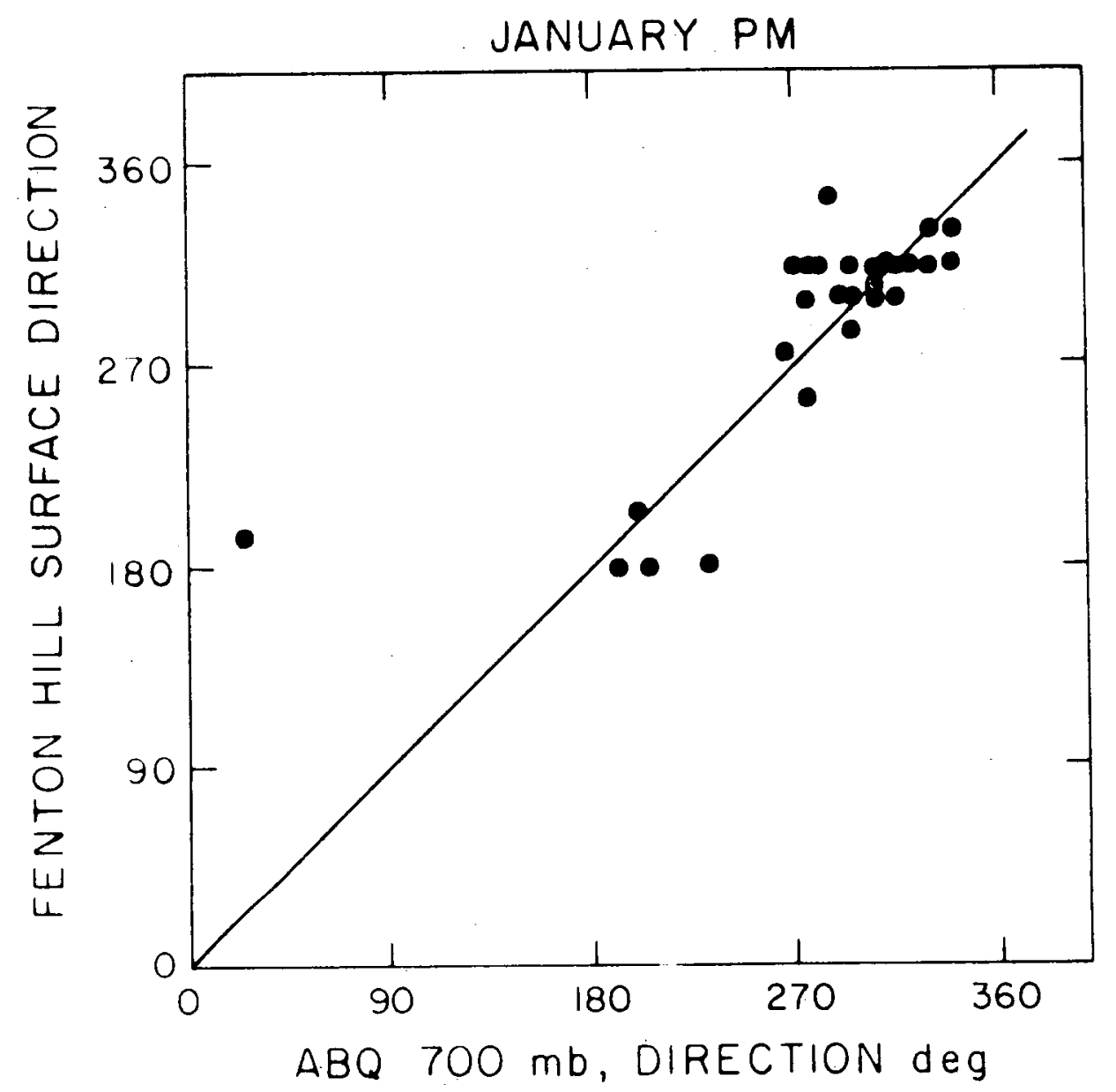

Fig. 7b. Scatter diagram relating surface $(2.7 \mathrm{~km} \mathrm{MSL})$ wind direction at Fenton $\mathrm{Hill}$ to the $700 \mathrm{mb}(3 \mathrm{~km} \mathrm{MSL})$ level winds from the Albuquerque upper air sounding. Comparisons are for winter afternoons. 


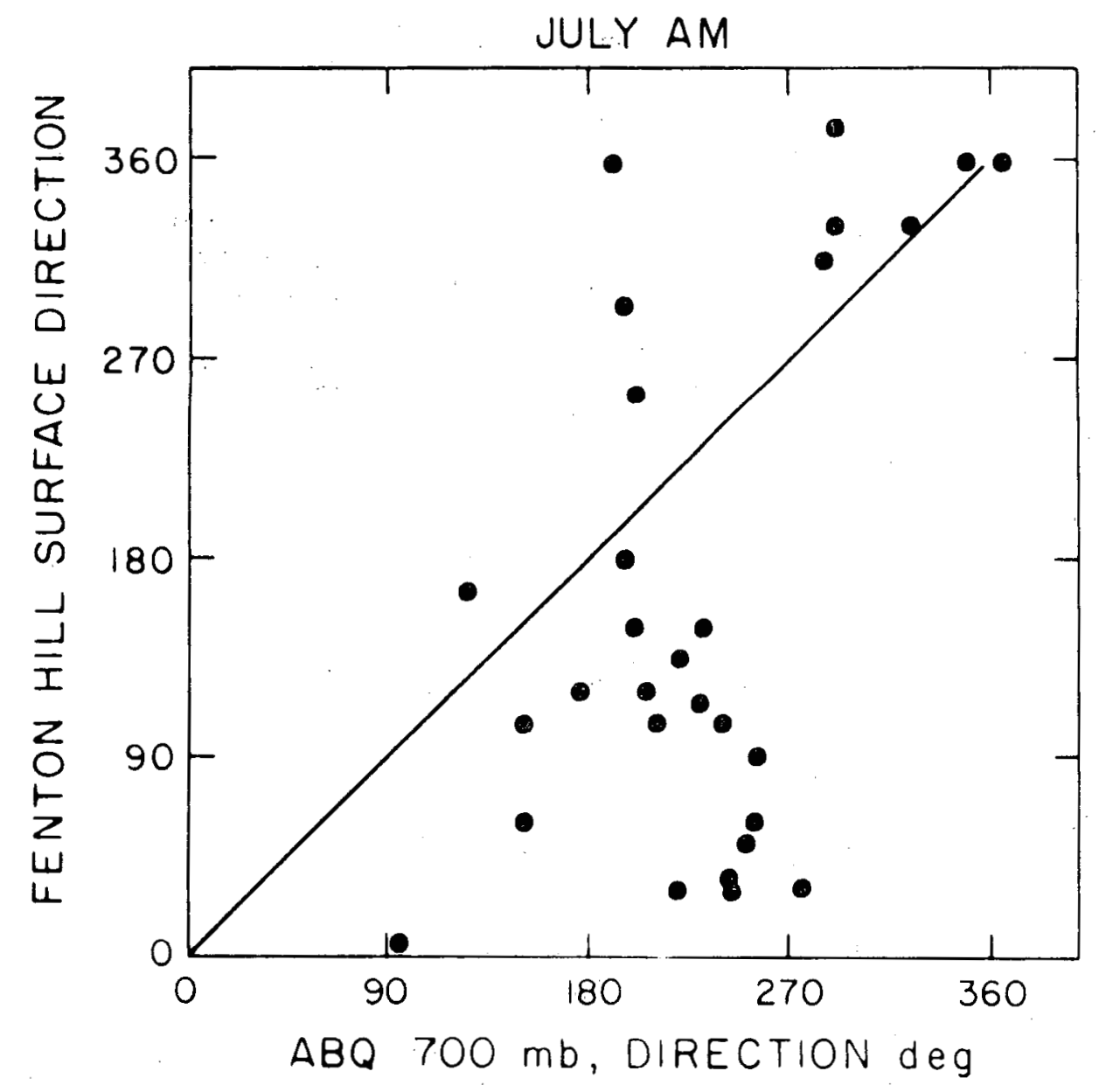

Fig. 7c. Scatter diagram relating surface $(2.7 \mathrm{~km} \mathrm{MSL})$ wind direction at Fenton $\mathrm{Hill}$ to the $700 \mathrm{mb}(3 \mathrm{~km} \mathrm{MSL})$ level winds from the Albuquerque upper air sounding. Comparisons are for summer morninas. 


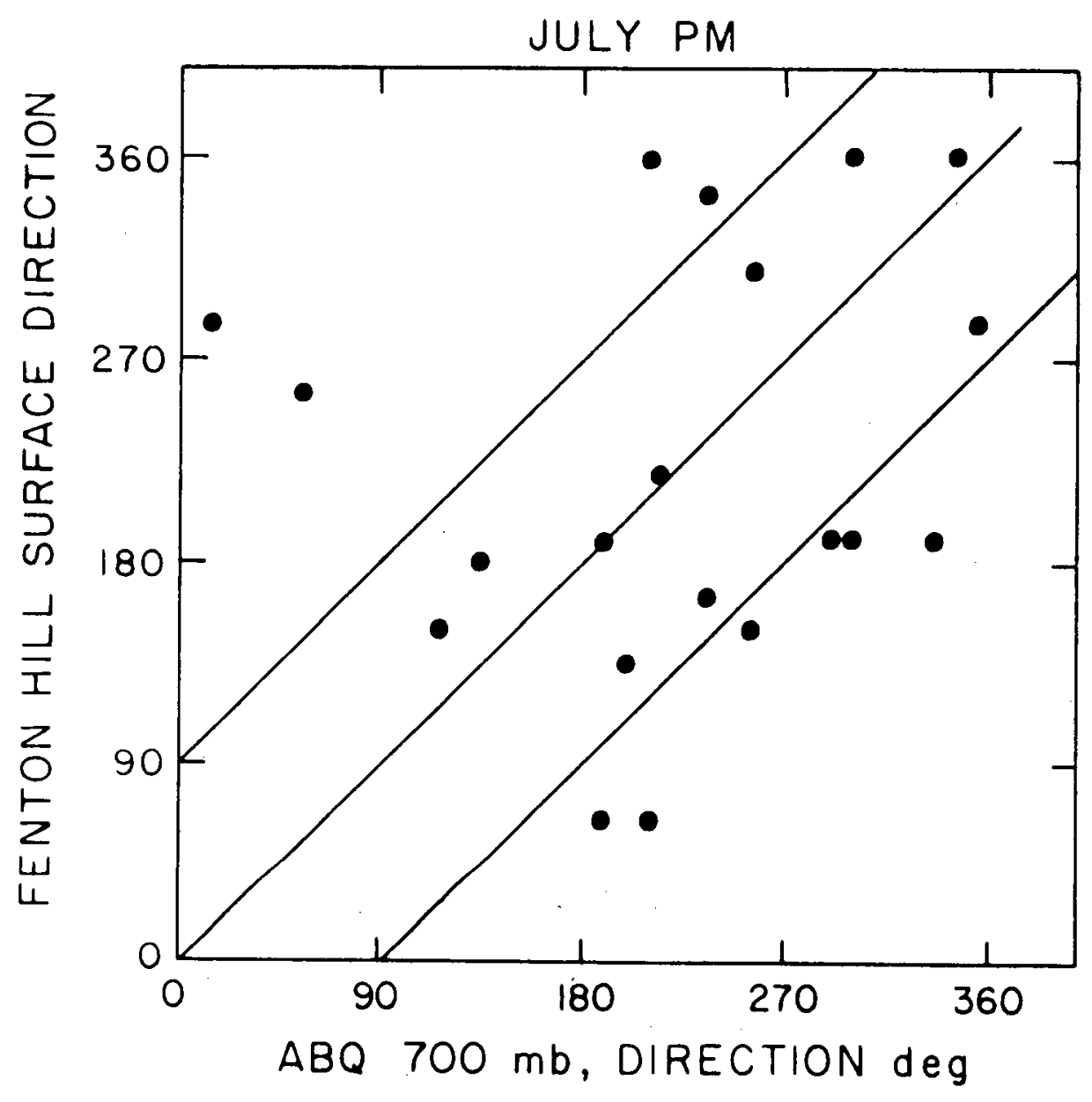

Fig. 7d. Scatter diagram relating surface $(2.7 \mathrm{~km} \mathrm{MSL)} \mathrm{wind}$ direction at Fenton $\mathrm{Hill}$ to the $700 \mathrm{mb}(3 \mathrm{~km} \mathrm{MSL})$ level winds from the Albuquerque upper air sounding. Comparisons are for summer afternoons. 